\title{
Yield, Quality and Economics of Rabi Fennel (Foeniculum vulgare Mill.) as Influenced by Different Time of Sowing, Variety and Spacing
}

\author{
Y. A. Tamboli ${ }^{1^{*}}$, A. U. Amin ${ }^{2}$, J. K. Patil ${ }^{3}$ and U.V. Patel ${ }^{3}$ \\ ${ }^{1}$ Department of Agronomy, Chaudhary Charan Singh Haryana Agricultural University, \\ Hisar, Haryana-125 004, India \\ ${ }^{2}$ Department of Agronomy, Seed Spices Research Station, Jagudan, S. D. Agricultural \\ University, Sardarkrushinagar, Gujarat-385 506, India \\ ${ }^{3}$ Department of Agronomy, Chimanbhai Patel College of Agriculture, S. D. Agricultural \\ University, Sardarkrushinagar, Gujarat-385 506, India \\ *Corresponding author
}

\section{A B S T R A C T}

\begin{tabular}{|c|}
\hline Keywords \\
\hline $\begin{array}{l}\text { Economics, Fennel, } \\
\text { Quality, Sowing } \\
\text { time, Variety, } \\
\text { Spacing, Yield }\end{array}$ \\
\hline Article Info \\
\hline $\begin{array}{l}\text { Accepted: } \\
18 \text { March } 2020 \\
\text { Available Online: } \\
10 \text { April } 2020\end{array}$ \\
\hline
\end{tabular}

A field experiment was conducted during rabi season of 2015-16 at Agronomy Instructional Farm, C. P. College of Agriculture, S. D. Agricultural University, Sardarkrushinagar to study the effect of sowing time, variety and spacing on yield, quality and economics of rabi fennel (Foeniculum vulgare Mill.). Eighteen treatment combinations comprising of three sowing times i.e., $3^{\text {rd }}$ week of October $\left(D_{1}\right), 1^{\text {st }}$ week of November $\left(D_{2}\right)$ and $3^{\text {rd }}$ week of November $\left(D_{3}\right)$, three varieties viz., Gujarat Fennel $2\left(\mathrm{~V}_{1}\right)$, Gujarat Fennel $11\left(\mathrm{~V}_{2}\right)$ and Gujarat Fennel $12\left(\mathrm{~V}_{3}\right)$ and two spacings i.e., $45\left(\mathrm{~S}_{1}\right) \mathrm{cm}$ and $60 \mathrm{~cm}\left(\mathrm{~S}_{2}\right)$ were evaluated in split plot design with four replications by keeping time of sowing as main plot and combination of variety and spacing in sub plot. The results revealed that crop sown in $3^{\text {rd }}$ week of October $\left(D_{1}\right)$ recorded significantly superior growth, yield, quality attributes as well as economics. While, variety GF $12\left(\mathrm{~V}_{3}\right)$ noticed higher values of growth, yield, quality attributes and economics. Similarly, superior growth parameters, yield and quality attributing characters and economics were registered with $45 \mathrm{~cm}\left(\mathrm{~S}_{1}\right)$ row spacing as compared to wider row spacing i.e. $60 \mathrm{~cm}\left(\mathrm{~S}_{2}\right)$. The test weight was not remarkably influenced by different spacing but marked effect of different times of sowing and varieties was recorded. This study revealed that higher growth, yield, quality attributing characters and economics can be achieved by sowing the fennel variety GF 12 during $3^{\text {rd }}$ week of October at $45 \mathrm{~cm}$ row spacing under North Gujarat Agro-climatic condition

\section{Introduction}

Fennel (Foeniculum vulgare Mill.) commonly known as variyali or saunf is native of Mediterranean countries and belonging to the family of Apiaceae. India is the world's largest producer, consumer and exporter of seed spices that's why India is known as home of spices. Gujarat and Rajasthan together contribute more than 80 per cent of the total seed spices production in the country and thus, both the states together are known 
as "Seed Spices Bowl" of India. Gujarat alone account for more than 90 per cent of the fennel production in the country. The area, production and productivity of fennel in India during 2014-15 were 54,000 hectares, 70,000 metric tonnes and $1296 \mathrm{~kg} \mathrm{ha}^{-1}$, respectively (Anon, 2015 ${ }^{\mathrm{a}}$.

Gujarat produced 63,845 tonnes from 30,200 ha area with average productivity of $2114 \mathrm{~kg}$ $\mathrm{ha}^{-1}$ (Anon, 2015 ${ }^{\mathrm{b}}$ ). Gujarat ranks first in average productivity not only in India, but at international level also. India earned Rs. 132 crores through export of fennel during 2015, which was 599 per cent higher than 2001 (Anon, 2015 ${ }^{\mathrm{c}}$.

Fennel seeds have a fragrant odour and a pleasent aromatic taste. They are widely used in various food preparation, candies, soups, sauces, pastries, pickles, liquors, bakery items etc. The leaves and seeds are digestive used for cough, flatulence, colic, thirst, constipation, dysentery and diarrhoea (Randhawa et al., 1978). Fennel seeds contain 1.4 to 4.0 per cent essential volatile oil, pale yellow in colour. It also contains carbohydrate $7.29 \mathrm{~g}$, dietary fibre $3.1 \mathrm{~g}$, protein $1.24 \mathrm{~g}$, fat $0.20 \mathrm{~g}$, potassium $414 \mathrm{mg}$, phosphorus $50 \mathrm{mg}$ and calcium $49 \mathrm{mg}$ per $100 \mathrm{~g}$ value. The main constituents of fennel oil are anethole and fenchone.

Time of sowing is an important factor to decide growth and production. Adjustment in sowing time creates favourable environmental condition for better performance of all physiological processes in plant and for escaping from pest and diseases which provides great opportunity to maximize the production. Selection of superior variety having resistance to biotic and abiotic stresses plays an important role for enhancing the crop yield. Optimum plant geometry being nonmonetary inputs exhibits dominant in increasing the yield of fennel crop.
A wider spacing increased photosynthetic area along with availability of more sunlight and minimize the competition within the crop plants for nutrient, air and water, but reduced plant population. Very meager information is available on optimum time of sowing, variety and spacing in fennel. Therefore, the investigation was conducted with an objective to find out suitable variety, optimum time of sowing and spacing for realizing higher growth and yield of rabi fennel.

\section{Materials and Methods}

A field experiment was conducted at Agronomy Instructional Farm, C. P. College of Agriculture, S. D. Agricultural University, Sardarkrushinagar during rabi season of 2015-16 to study the effect of sowing time, variety and spacing on yield, quality and economics of rabi fennel (Foeniculum vulgare Mill.). Eighteen treatment combinations comprising of three sowing times i.e., $3^{\text {rd }}$ week of October $\left(\mathrm{D}_{1}\right), 1^{\text {st }}$ week of November $\left(D_{2}\right)$ and $3^{\text {rd }}$ week of November $\left(\mathrm{D}_{3}\right)$, three varieties viz., Gujarat Fennel 2 $\left(\mathrm{V}_{1}\right)$, Gujarat Fennel $11\left(\mathrm{~V}_{2}\right)$ and Gujarat Fennel $12\left(\mathrm{~V}_{3}\right)$ and two spacings i.e., $45\left(\mathrm{~S}_{1}\right)$ $\mathrm{cm}$ and $60 \mathrm{~cm}\left(\mathrm{~S}_{2}\right)$ were evaluated in split plot design with four replications by keeping time of sowing as main plot and combination of variety and spacing as sub plots.

Geographically, Sardarkrushinagar is situated at 24 $/ 19^{\prime}$ North latitude and $72^{\circ} / 19$ ' East longitude with an elevation of 154.52 meters above mean sea level. The climate type of this area is sub-tropical. The soil of experimental plot was loamy sand in texture, low in organic carbon and available nitrogen, medium in available phosphorus and potash content

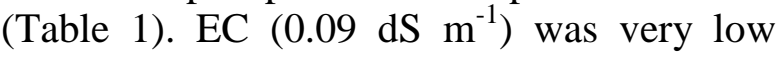
showing that the soil was free from salinity hazard. The crop was fertilized with recommended dose of fertilizer i.e. $90 \mathrm{~kg} \mathrm{~N}$ and $30 \mathrm{~kg} \quad \mathrm{P}_{2} \mathrm{O}_{5}$ per hectare. As per 
treatments, the required quantity of seeds of fennel varieties viz., GF 2, GF 11 and GF 12 were taken by keeping uniform seed rate of 5 $\mathrm{kg}$ per hectare. To save the crop from disease viz., Rumularia blight and pest viz., Aphid during the life cycle of crop, adequate and timely plant protection measures were taken by spraying recommended fungicide, i.e. Dithane-M-45 (0.2 \%) and pesticide i.e.
Dimethoate $(0.03 \%)$ in the field. The five plants were selected from each plot for recording various growths and yield attributes. The harvesting of rows of net plot was done manually. The net plot wise yield was recorded and converted in $\mathrm{kg}$ per hectare. The statistical analysis of data for each characters studied in the experiment was carried out as per design of the experiment.

\section{Table.1 Chemical properties of experimental field}

\begin{tabular}{|c|c|c|c|c|}
\hline \multicolumn{5}{|c|}{ Chemical properties } \\
\hline (a) & Soil $\mathrm{pH}(1: 2.5$, Soil : Water ratio $)$ & 7.0 & 7.4 & $\begin{array}{c}\text { Potentiometric method } \\
\text { (Jackson, 1973) }\end{array}$ \\
\hline (b) & Electrical Conductivity (dS/m) & 0.09 & 0.10 & $\begin{array}{l}\text { Schofield method } \\
\text { (Jackson, 1973) }\end{array}$ \\
\hline (c) & Organic carbon $(\%)$ & 0.17 & 0.15 & $\begin{array}{l}\text { Walkley and Black's method (Jackson, } \\
\text { 1973) }\end{array}$ \\
\hline (d) & Available N (kg/ha) & 159 & 147 & $\begin{array}{l}\text { Alkaline Potassium Permanganate method } \\
\text { (Jackson, 1973) }\end{array}$ \\
\hline (e) & Available $\mathrm{P}_{2} \mathrm{O}_{5}(\mathrm{~kg} / \mathrm{ha})$ & 39 & 36 & $\begin{array}{l}\text { Olsen's method } \\
\text { (Olsen et al., 1954) }\end{array}$ \\
\hline (f) & Available $\mathrm{K}_{2} \mathrm{O}$ (kg/ha) & 274 & 271 & Flame Photometer method (Jackson, 1973) \\
\hline
\end{tabular}

Estimation of quality attributes

\section{Protein content $(\%)$}

The estimation of nitrogen in seed was done by adopting the micro Kjeldahl's method as described by Jackson (1967). Protein content calculated by using following formula (Bhuiya and Chaudhary, 1974).

\section{Protein content $(\%)=$ \\ Nitrogen content $(\%) \times 6.25$}

Volatile oil content (\%)

The volatile oil content was determined in percentage by steam distillation method (AOAC, 1970). The volume of oil so obtained was converted into percentage by using following formula.

Volatile oil

Vol. of oil (ml)

$(\%)(\mathrm{v} / \mathrm{w})$

$=$

Wt. of sample

Volatile oil yield $\left(\mathrm{kg} \mathrm{ha}^{-1}\right)$

Volatile oil yield $\left(\mathrm{kg} \mathrm{ha}^{-1}\right)$ was calculated for different treatments by using the following formula.

Volatile oil content in seed (\%)

Volatile oil $\times$ seed yield ( $\mathrm{kg}$ ha-1)

yield (kg ha- 1$)=$

100 


\section{Results and Discussion}

\section{Effect of time of sowing}

Data exhibited in Table 2 and 3 inferred that significantly the higher plant height (155.68 $\mathrm{cm})$, total number of branches per plant (18.28), test weight $(8.00 \mathrm{~g})$, seed yield (1423 $\left.\mathrm{kg} \mathrm{ha}^{-1}\right)$ and stover yield $\left(4080 \mathrm{~kg} \mathrm{ha}^{-1}\right)$, productivity per day $\left(8.37 \mathrm{~kg} \mathrm{ha}^{-1}\right.$ day $\left.^{-1}\right)$, volatile oil content $(1.59 \%)$, volatile oil yield $\left(24.20 \mathrm{~kg} \mathrm{ha}^{-1}\right)$, protein content $(13.96 \%)$, gross realization $\left(108728\right.$ ₹ $\left.^{-1} \mathrm{~h}^{-1}\right)$, net realization $\left(64065 \boldsymbol{F}^{-1}\right.$ ha $\left.^{-1}\right)$, net income per day (377 $₹^{-}$ha $^{-1}$ day $^{-1}$ ) and BCR (2.43) (Fig. 1) were recorded under early sown crop i.e $3^{\text {rd }}$ week of October $\left(D_{1}\right)$ as compared to late sown i.e. $1^{\text {st }}$ week of November $\left(\mathrm{D}_{2}\right)$ and $3^{\text {rd }}$ week of November $\left(D_{3}\right)$. Whereas, seed and stover yield, productivity per day and protein content were statistically at par with $1^{\text {st }}$ week of November.

The maximum seed yield was recorded under early sown crop i.e. $3^{\text {rd }}$ week of October $\left(D_{1}\right)$ was 7.7 and 31.8 per cent over $1^{\text {st }}$ week of November $\left(\mathrm{D}_{2}\right)$ and $3^{\text {rd }}$ week of November $\left(\mathrm{D}_{3}\right)$, respectively. Favourable climatic condition throughout the growth period had increased seed yield and consequently net profit, net income per day and BCR.

Nitrogen supply seems to be involved in an increased conversion of primary fatty acids metabolites end product of fatty acids, which resulted in increased volatile oil content in seed and important role in synthesis of different amino acid, which constitutes building blocks of protein and that might have resulted in higher protein content. Whereas, Increased in temperature at maturity stage under late sown condition increased the loss of volatile oil through volatilization might have reduced the volatile oil content of seed. These findings are in accordance with the results of Ayub et al., (2008), Bagari et al.,
(2010), Selim et al., (2013), Singh et al., (2005) and Yadav et al., (2000).

\section{Effect of variety}

The perusal of data presented in Table 2 and 3 revealed that the significantly higher plant height $(153.16 \mathrm{~cm})$, total number of branches per plant (18.10), test weight $(8.01 \mathrm{~g})$, seed yield $\left(1411 \mathrm{~kg} \mathrm{ha}^{-1}\right)$ and stover yield $(4030 \mathrm{~kg}$ $\left.\mathrm{ha}^{-1}\right)$, productivity per day $\left(8.75 \mathrm{~kg} \mathrm{ha}^{-1} \mathrm{day}^{-1}\right)$, volatile oil content $(1.53 \%)$, volatile oil yield $\left(24.22 \mathrm{~kg} \mathrm{ha}^{-1}\right)$, protein content $(14.52 \%)$, gross realization $\left(107853 \mathrm{~F}^{-1} \mathrm{ha}^{-1}\right)$, net realization (63556 $₹^{-}$ha $\left.^{-1}\right)$, net income per day (393 $₹^{-}$ha $^{-1}$ day $^{-1}$ ) and BCR (2.42) (Fig. 1) was recorded under variety GF 12 over GF 11 and GF 2.

Whereas, stover yield, productivity per day and volatile oil content were statistically at par with GF 11. Inherent characteristic and genetic potential of a particular variety plays a role in exploitation of higher yield, volatile oil and protein content and there by remuneration. Accordingly, GF $12 \quad\left(\mathrm{~V}_{3}\right)$ expressed its superiority. Similar results were observed by Malik et al., (2009), Meena and Singh (2013) and Sengupta et al., (2014).

\section{Effect of spacing}

The data presented in Table 2 and 3 revealed that significantly the higher plant height $(151.89 \mathrm{~cm})$, total number of branches per plant (17.13), seed yield (1346 kg ha ${ }^{-1}$ ) and stover yield (3914 kg ha-1), productivity per day $\left(8.34 \mathrm{~kg} \mathrm{ha}^{-1} \mathrm{day}^{-1}\right)$, volatile oil yield $\left(21.67 \mathrm{~kg} \mathrm{ha}^{-1}\right)$, gross realization (102883 ₹ ha $\left.^{-1}\right)$, net realization $\left(58586 ₹^{-} h^{-1}\right)$, net income per day $\left(362 ₹^{-}\right.$ha $^{-1}$ day $\left.^{-1}\right)$ and BCR (2.31) (Fig. 1) was recorded with $45 \mathrm{~cm}\left(\mathrm{~S}_{1}\right)$ row spacing as compared to wider row spacing i.e. $60 \mathrm{~cm}\left(\mathrm{~S}_{2}\right)$. Test weight, volatile oil and protein content of seed were not differed remarkably due to different spacings. 
Table.2 Effect of sowing time, variety and spacing on growth, yield and quality parameters of rabi fennel

\begin{tabular}{|c|c|c|c|c|c|c|c|c|c|}
\hline \multirow[t]{2}{*}{ Treatments } & \multirow{2}{*}{$\begin{array}{c}\text { Plant } \\
\text { height } \\
\text { (cm) }\end{array}$} & \multirow{2}{*}{$\begin{array}{c}\text { Total } \\
\text { number of } \\
\text { branches } \\
\text { per plant }\end{array}$} & \multirow{2}{*}{$\begin{array}{c}\text { Test } \\
\text { weight }(\mathrm{g})\end{array}$} & \multicolumn{2}{|c|}{ Yield (kg ha $\left.{ }^{-1}\right)$} & \multirow{2}{*}{$\begin{array}{l}\text { Productivity } \\
\text { per day (kg } \\
\left.\text { ha }^{-1} \text { day }^{-1}\right)\end{array}$} & \multirow{2}{*}{$\begin{array}{c}\text { Volatile oil } \\
\text { content } \\
(\%)\end{array}$} & \multirow{2}{*}{$\begin{array}{c}\text { Volatile } \\
\text { oil yield } \\
\left(\mathrm{kg} \mathrm{ha}^{-1}\right)\end{array}$} & \multirow{2}{*}{$\begin{array}{c}\text { Protein } \\
\text { content } \\
(\%)\end{array}$} \\
\hline & & & & Seed & Stover & & & & \\
\hline \multicolumn{10}{|l|}{ Times of sowing (D) } \\
\hline$D_{1}: 3^{\text {rd }}$ week of October & 155.68 & 18.28 & 8.00 & 1423 & 4080 & 8.37 & 1.59 & 24.20 & 13.96 \\
\hline$D_{2}: 1^{\text {st }}$ week of November & 151.18 & 16.95 & 7.64 & 1321 & 3996 & 8.20 & 1.47 & 20.29 & 13.73 \\
\hline$D_{3}: 3^{\text {rd }}$ week of November & 141.44 & 14.87 & 6.78 & 1079 & 3365 & 7.14 & 1.39 & 16.02 & 13.08 \\
\hline S.Em. \pm & 3.11 & 0.16 & 0.16 & 33 & 105 & 0.21 & 0.02 & 0.46 & 0.14 \\
\hline C.D. at $5 \%$ & 10.76 & 0.54 & 0.54 & 115 & 362 & 0.72 & 0.06 & 1.61 & 0.49 \\
\hline C.V. \% & 10.19 & 12.07 & 10.20 & 12.82 & 13.45 & 12.97 & 6.19 & 11.27 & 5.15 \\
\hline \multicolumn{10}{|l|}{ Varieties (V) } \\
\hline$V_{1}:$ GF 2 & 146.09 & 15.64 & 6.94 & 1138 & 3552 & 7.06 & 1.44 & 16.20 & 12.89 \\
\hline$V_{2}:$ GF 11 & 149.05 & 16.38 & 7.46 & 1272 & 3860 & 7.90 & 1.48 & 20.09 & 13.36 \\
\hline$V_{3}:$ GF 12 & 153.16 & 18.10 & 8.01 & 1411 & 4030 & 8.75 & 1.53 & 24.22 & 14.52 \\
\hline 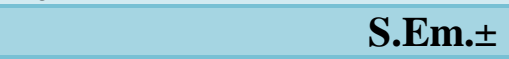 & 1.58 & 0.13 & 0.14 & 25 & 71 & 0.16 & 0.02 & 0.39 & 0.11 \\
\hline C.D. at $5 \%$ & 4.50 & 0.38 & 0.39 & 72.36 & 202 & 0.45 & 0.05 & 1.10 & 0.31 \\
\hline \multicolumn{10}{|l|}{ Spacings (S) } \\
\hline$S_{1}: 45 \mathrm{~cm}$ & 151.89 & 17.13 & 7.51 & 1346 & 3914 & 8.34 & 1.48 & 21.67 & 13.68 \\
\hline$S_{2}: 60 \mathrm{~cm}$ & 146.99 & 16.28 & 7.44 & 1202 & 3713 & 7.47 & 1.48 & 18.67 & 13.50 \\
\hline S.Em. \pm & 1.29 & 0.11 & 0.11 & 21 & 58 & 0.13 & 0.01 & 0.31 & 0.09 \\
\hline C.D. at 5\% & 3.67 & 0.31 & NS & 59.08 & 165 & 0.37 & NS & 0.90 & NS \\
\hline Sig. interaction & $\mathrm{D} \times \mathrm{S}$ & - & - & $\mathrm{D} \times \mathrm{S}$ & $\mathrm{D} \times \mathrm{S}$ & - & - & - & - \\
\hline C.V. \% & 5.17 & 10.28 & 8.91 & 9.76 & 9.10 & 9.83 & 5.74 & 9.36 & 3.97 \\
\hline
\end{tabular}


Table.3 Effect of sowing time, variety and spacing on economics of rabi fennel

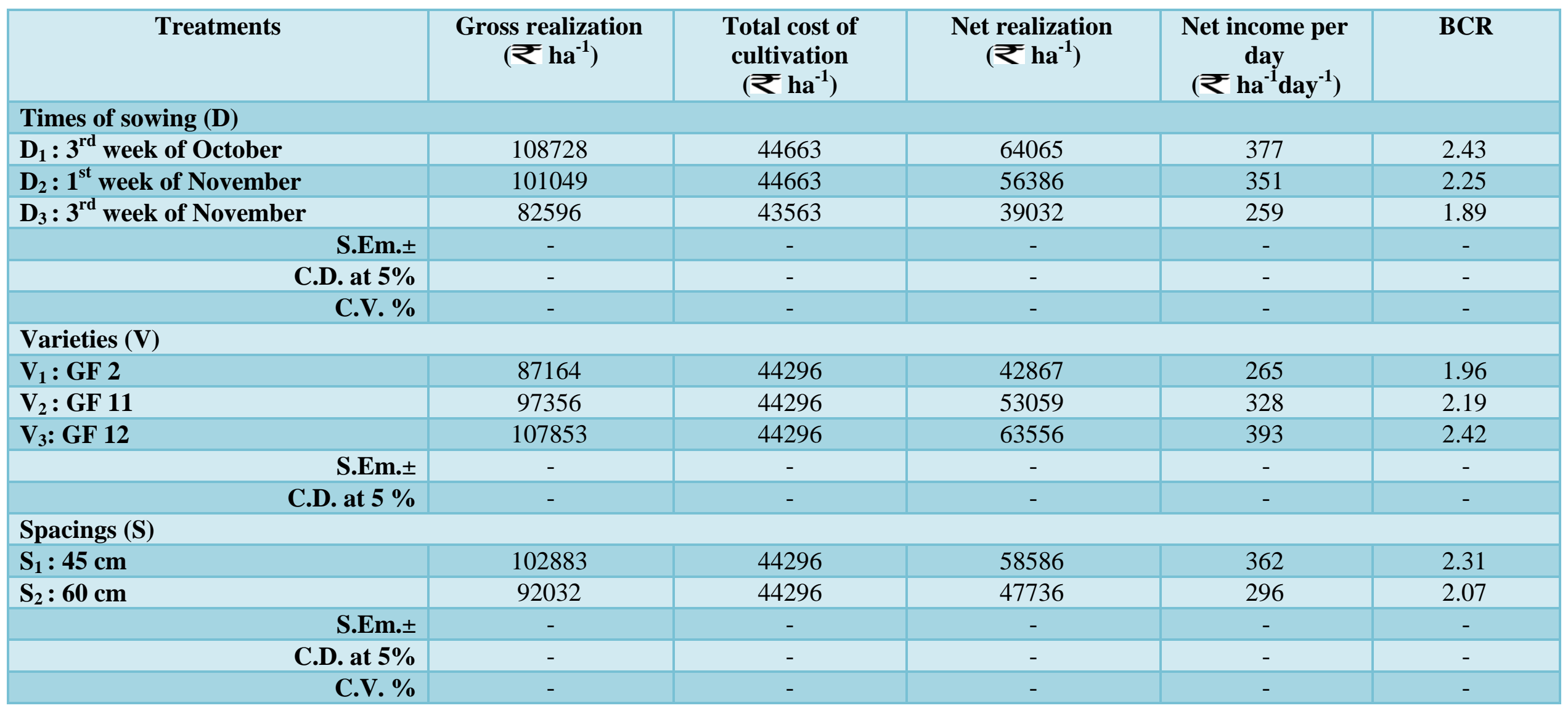


Table.4 Interaction effect of time of sowing and spacing (D x S)

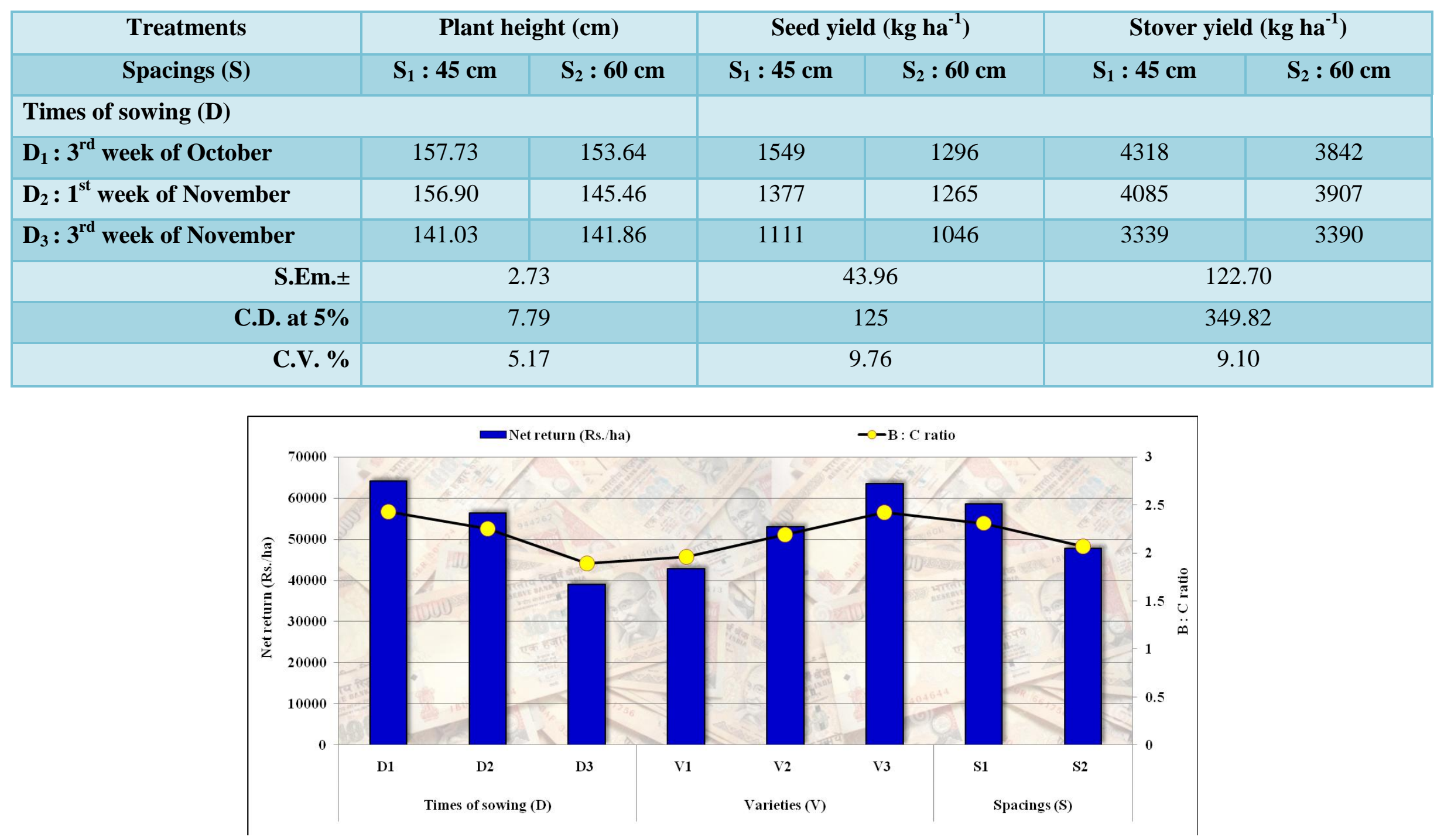

Fig.1Economics of rabi fennel as influenced by times of sowing, varieties and row spacings 
Optimum space available for individual plants i.e. $45 \mathrm{~cm}\left(\mathrm{~S}_{1}\right)$ and adequate plants per unit area might have resulted in better utilization of resources viz., space, nutrients, moisture, carbon dioxide and radiant energy to improve vegetative growth consequently reproductive growth and ultimately increase in net profit, net income per day and BCR. These findings are corroborate with the results of Amin et al., (2005), Singh et al., (2009) and Yadav et al., (2000).

Interaction effect of sowing time and spacing (D x S)

The data presented in Table 4 revealed that the significantly the highest plant height $(157.73 \mathrm{~cm})$, seed yield $\left(1549 \mathrm{~kg} \mathrm{ha}^{-1}\right)$ and stover yield (4318 $\left(\mathrm{kg} \mathrm{ha}^{-1}\right)$ was recorded when crop sown in $3^{\text {rd }}$ week of October at 45 $\mathrm{cm}$ row spacing $\left(\mathrm{D}_{1} \mathrm{~S}_{1}\right)$. Whereas in plant height at harvest was found statistically at par with treatment combinations of $\mathrm{D}_{2} \mathrm{~S}_{1}$ and $\mathrm{D}_{1} \mathrm{~S}_{2}$ but in stover yield it was found statistically at par with $\mathrm{D}_{2} \mathrm{~S}_{1}$ only. The favourable climatic condition with availability of optimum space for individual plants and optimum plants per unit area increased seed and stover yield. These finding corroborated the results reported earlier by Ayub et al., (2008), Selim et al., (2013), Singh et al., (2005) and Singh et al., (2006).

On the basis of field experiment conducted at Sardarkrushinagar it is concluded that, higher yield and net profit can be achieved by sowing the fennel variety GF 12 during $3^{\text {rd }}$ week of October at $45 \mathrm{~cm}$ row spacing under North Gujarat Agro-climatic condition.

\section{References}

A.O.A.C. 1970 Official methods of Analysis. Association of official Agriculture Chemists, Washington.
Amin, A.U., Singh, A., Patel, B. S. and Patel, J. K. 2005. Effect of various row spacing and nitrogen levels on drilled Rabi fennel (Foeniculum vulgare Mill.). Agricultural Science Digest. 25 (1): 4446.

Anonymous, 2015a. State of Indian Agriculture 2014-15. Department of Agriculture and Co-operation, Ministry of Agriculture, Government of India, New Delhi. pp. 202-205.

Anonymous, 2015b. District-wise Area, Production and yield in Gujarat State during 2014-15. Directorate of Agriculture Gujarat State Gandhinagar. pp. 32.

Anonymous, 2015c. Item-wise export of spices from India during 201415.Directorate General of Commercial Intelligence and Statistics, Ministry of Commerce and Industry, Government of India. pp. 42.

Ayub, M., Nadeem, M. A., Tanveer, A., Tahir, M., Saqib, M.T.Y. and Nawaz, R. 2008. Effect of different sowing methods and times on the growth and yield of fennel (Foeniculum vulgare Mill.). Pakistan Journal of Botany.40 (1): 259-264.

Bagari, S., Singh, P. P., Naruka, I. S., Rathore, S. S. and Shaktawat, R. P. S. 2010. Effect of date of sowing and nitrogen levels on growth, yield and quality of fennel (Foeniculum vulgare Mill.). Indian Journal of Horticulture. 67(4): 518-524.

Bhuiya, Z.H. and Chaudhary, S.V. 1974. Effect of NPK and S on quality of groundnut. Asian Journal of Agricultural Science. 44(1): 751-754.

Jackson, M. L. 1973. Soil chemical analysis. Prentice Hall of India Pvt. Ltd., New Delhi. pp. 183-192.

Malik, T. P., Tahlan, S. K. and Thakral, K. K. 2009. Performance of fennel (Foeniculum vulgare Mill.) genotype 
for seed yield. Annals of Horticulture. 2(2): 243-245.

Meena, M. L. and Singh, D. 2013. On-farm assessment of fennel varieties in Rajasthan. Journal of Spices and Aromatic crops. 22 (2): 200-202.

Olsen, S. R., Cole, V. C., Watanable, P. S. and Dean, L. A. 1954. Estimation of available phosphorus in soil by extraction with sodium bicarbonate. U.S.D.A., Circ. No. 939.

Randhawa, G. S., Bains, D. S., Mahajan, V. P. and Singh, K. 1978. Effect of sowing date and levels of nitrogen on the yield of fennel (Foeniculum vulgare Mill.). Journal of Research, Punjab Agricultural University. 15 (3): 229-235.

Selim, S. M., Ebtsam, M. M. A. Tawfic, M. S. H. and Abou-Sreea, A. I. 2013. Effect of sowing date, row spacing and biofertilizer on yield and oil quality of fennel (Foeniculum vulgare Mill.). Australian Journal of Basic and Applied Science. 7 (2): 882-894.

Sengupta, S. K., Verma, B. K. and Naidu, A. K. 2014. Genetic variability study in fennel (Foeniculum vulgare Mill.). International Science Journal. 1 (1): 6264.
Singh, S. K., Tripathi, S. M. and Dwivedi, A. K. 2009. Effect of planting dates, sowing method and row spacing on yield of fennel (Foeniculum vulgare Mill.). Annals of Horticulture. 2(2): 249-250.

Singh, S., Buttar, G. S. and Singh, S. P. 2005. Fennel (Foeniculum vulgare Mill.) response to sowing dates and row spacings. Haryana Journal of Agronomy. 21 (2): 202-203.

Singh, S., Butter, G. S. and Singh S. P. 2006. Growth, yield and heat unit requirement of fennel (Foeniculum vulgare Mill.) as influenced by date of sowing and row spacing under semi-arid region of Punjab. Journal of Medicinal and Aromatic Plant Science. 28 (3): 363-365. Yadav, A. C., Yadav, J. S. and Dhankhar, O. P. 2000. Effect of row and plant spacing on growth and yield of fennel (Foeniculum vulgare Mill.) c.v. PF-35. In: Spices and aromatic: challenges and opportunities in the new century. Centennial Conference on Spices and Aromatic plants, 20-23 September, 2000, Calicut (pp. 199-201). Indian Society for Spices, Calicut.

\section{How to cite this article:}

Tamboli, Y. A., A. U. Amin, J. K. Patil and Patel, U.V. 2020. Yield, Quality and Economics of Rabi Fennel (Foeniculum vulgare Mill.) as Influenced by Different Time of Sowing, Variety and Spacing. Int.J.Curr.Microbiol.App.Sci. 9(04): 2358-2366.

doi: https://doi.org/10.20546/ijcmas.2020.904.283 